\title{
BIODIVERSITY AND THE SUSTAINABILITY OF MARINE FISHERIES
}

\author{
By George W. Boehlert
}

\section{. . a National \\ Research Council \\ workshop identified \\ "fisheries operations" \\ as the most \\ important}

anthropogenic effect

on marine

biodiversity among

five major critical

environmental

issues . . .
$\mathrm{U}$ TILIZATION OF MARINE resources is the oldest impact on the ocean environment by humans: with widespread development of fisheries. it has become the major ecological impact. Humans have fished since before recorded history. Over the last 50 years, the global marine catch has increased approximately fourfold, to $>80$ million tons, but the rate of increase has slowed (FAO, 1993). Historically, fisheries exploited near-shore and coastal resources, but the expansion of far seas fisheries in the second half of the 20th century led to exploitation in all the world's oceans (Garcia and Newton, 1994). Thus it is little wonder that a National Research Council workshop identified "fisheries operations" as the most important anthropogenic effect on marine biodiversity among five major critical environmental issues (NRC, 1995) and suggested taking a regional approach to examine human impacts on marine biodiversity, consistent with the broad geographic range of fisheries.

A general definition of biodiversity is "the collection of genomes, species, and ecosystems occurring in a geographically defined region" (NRC. 1995); fisheries impact baseline diversity at each of these levels. At the genetic level, fisheries change population characteristics (e.g., age distribution. reproduction, stock structure), resulting in alterations to the genome. At the species level. fisheries affect species composition and interactions. Finally, through effects of by-catch. habitat alteration, and altered energy flow, fisheries impact the diversity of marine habitats and the function of ecosystems. In this paper, I describe how marine fisheries affect biodiversity and discuss fisheries management in light of the importance of biodiversity to the sustainability of marine fisheries.

\section{General Patterns in the Development of Fisheries}

Common patterns of growth among diverse fisheries provide a context to examine their effects

George W. Boehlert. NMFS Southwest Fisheries Science Center, Pacific Fisheries Environmental Group, 1352 Lighthouse Avenue, Pacific Grove, CA 93950-2097. USA. on biodiversity. As fisheries develop, they go through a "fishing up" process (Regier and Loftus, 1972); the geographic range of the fishery expands as local populations of preferred species decline. With time. the fishery moves to less desirable species. Coral reef fisheries (as an example of small scale demersal fisheries) initially exploit larger, often predatory species; as these are reduced in number, the fishery shifts to smaller species, and ultimately to the smaller individuals within the small species (Gobert, 1992). Small scale pelagic fisheries show a similar pattern, with catch progressing from large species (e.g., tunas) to smaller clupeoids; with continued exploitation, small, fast-growing species dominate the system (Formacion and Saila 1994).

Similar patterns emerge for commercial marine fisheries on larger geographic scales. At the regional scale, Deimling and Liss (1994) examined three fisheries in the eastern North Pacific from Alaska to central California. Although the three had many differences, the fishing up process followed a similar sequence: 1) the geographic range of each fishery expanded: 2) landings of the most desirable species increased, peaked, and then decreased; and 3) the species composition of the landings changed. Each of these effects may translate to changes in biodiversity. Finally, on a worldwide scale, international competition and improving technology have allowed marine fisheries to expand to deeper slope waters and the far seas as near-shore or coastal fisheries became depleted (Garcia and Newton. 1994). The total catch of world fisheries has not markedly increased in recent years, but the distribution of catch has changed; since 1970, the highest rates of increase in marine catch have been for krill, cephalopods, and tunas (FAO, 1993). The potential for further expansion of fisheries has declined as wider ocean areas become exploited (Pauly and Christensen, 1995).

\section{Marine Fisheries and Genetic Diversity}

In a natural, unexploited ccosystem, life history strategies evolve through natural selection to match key characteristics of the environment. including fluctuations on varied spatial and temporal 
scales (Adams, 1980; Parrish el al., 1981). Important biological features include size, maximim age. growth rates, reproductive characteristics, a ad the local degree of genetic adaptation (Carvalh), 1993). Fisheries increase the rate of mortality on the target population and, with time, act as a agent of directional selection (Wohlfarth, 1986).

Examples of overexploitation in marine fisheries abound (NOAA, 1993). Decreased population size as a result of fishing could conceivably alter genetic diversity within a species through genetic drift, but for marine species the fishery would likely collapse economically before the population was sufficiently low for genetic drift to be an important factor. Good evidence exists, however, for changes in population characteristics in exploited species. Because fishing is size-selective, it will tend to remove the larger, and thus older, members of the population. Many species of rockfish (Sebastes) on the west coast of North America reach ages higher than $100 \mathrm{yr}$ (Leaman. 1991). Population declines from fishing result in drastic changes in the age composition of many of these species. The dominant age modes for lightly and heavily exploited populations of $S$. alutus, for example. were 30 and 12 yr of age. and fish older than age 20 represented 73 and $7 \%$ of the samples, respectively (Fig. 1). A tishery for orange roughy (Hoplostethus atlanticus) reduced biomass by some $70 \%$ and selectively removed older. more heterozygous individuals over a period of $6 \mathrm{yr}$ (Smith et al.. 1991). Whether alterations to the age structure reflect changes in genetic diversity in fishes is unknown. but genetic regulation of longevity has been observed in metazoans (Larsen et al., 1995). Similar to changes in age distribution are effects on mean size and growth rate. A 35-yr decline in mean size of pink salmon was associated with fishery removalls of larger fish (McAllister et al., 1992). Selective harvest will remove intrinsically faster-growing fish (Parma and Deriso. 1990). and the extent to which growth is genetically determined may alter genetic diversity through exploitation (Wohlfarth, 1986).

Reproductive characteristics evolve to meet selective pressures, including environmental conditions (see Parrish et al.. 1981), and the response to exploitation has been well studied (Garrod and Horwood, 1984). The most common change is increased fecundity when population size is decreased, a so-called compensatory change (DeMartini et al.. 1993). Such changes have been observed through cycles of population size associated with exploitation, but whether fecundity changes are phenotypic or genotypic is not clear (Rijnsdorp, 1993). Age at maturity schedules also vary within species, and exploitation will most often select for younger ages at maturity. Borisov (1979) modeled the reproductive contribution of three subgroups in a year class of Atlantic cod differing in age at maturity (6.8, and $11 \mathrm{yr}$ ). After 7 yr of relatively intensive exploitation. the late-maturing subgroup made virtually no contribution to reproduction, and thus the relative contribution by the early maturing subgroup increased. These results are supported by examination of cod maturity schedules after $40 \mathrm{yr}$ of tishing: the age when $50 \%$ of the year class was mature changed from $>10 \mathrm{yr}$ of age in the 1930-1940s to $<7$ in the 1960-1970s (Fig. 2).

Do compensatory changes in growth and reproduction improve a species" resiliency? It has been argued that these are natural balances to allow fish stocks to rebound from overexploitation or other events leading to low stock size (McFadden, 1977). Compensation, as an important mechanism in density-dependent population regulation, is a key element in sustainable resource use (Rosenberg et al., 1993). The scope for compensation, however, may be dependent on a range of genotypes in the population: through directed selection, fishing can change the genome, and it is conceivable that it could also change the species" ability to respond in compensatory ways.

Marine stocking or ocean ranching is a "growth" sector of fisheries and represents an emerging area of concern for the genetic diversity of exploited marine animals. Although best known for anadromous salmonids. stock enhancement of marine fishes and invertebrates is also being conducted (Morikawa, 1994). Early enthusiasm about technological intervention in the genetics of wild stocks has been replaced by a more cautious approach. Moav et al. (1978) suggested improving commercially exploited wild animals by crossing with domesticated breeds, thereby producing heterotic hybrids that would "upgrade the wild stocks." More recent concerns, however, are expressed about the potential negative effects. In freshwater systems, Wilcove et al. (1992) suggested that "Introduced genes can be as harmful as introduced species, especially when hatchery-

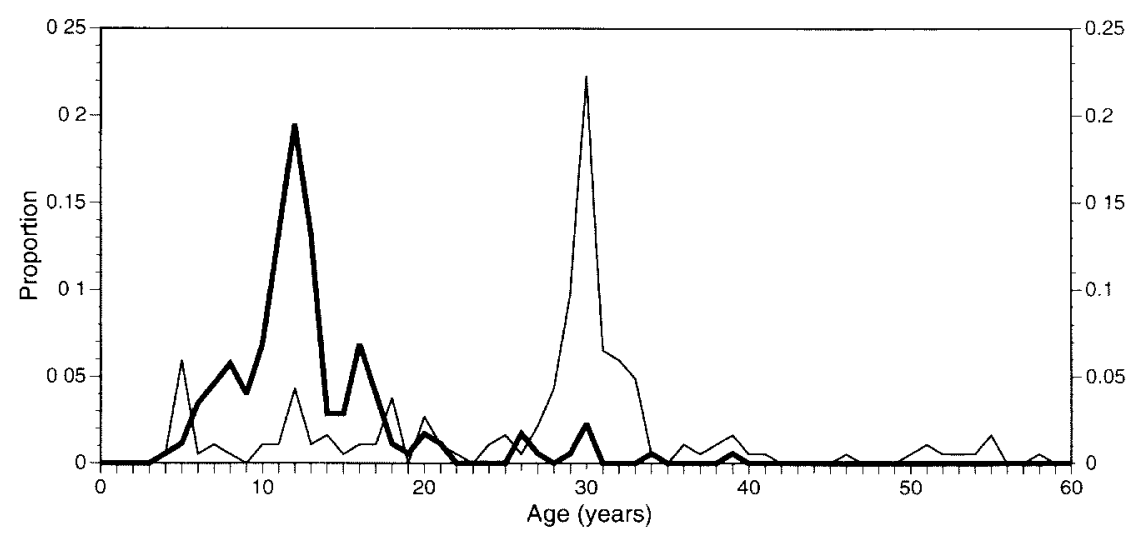

Fig. 1: Differences in age composition between samples of heavily exploited (fishing mortality; $F=0.60$, thick line) and lightly exploited $(F=0.02$, thin line) stocks of Sebastes alutus from off Vancouver Island, British Columbia. Data from Leaman (1991). 


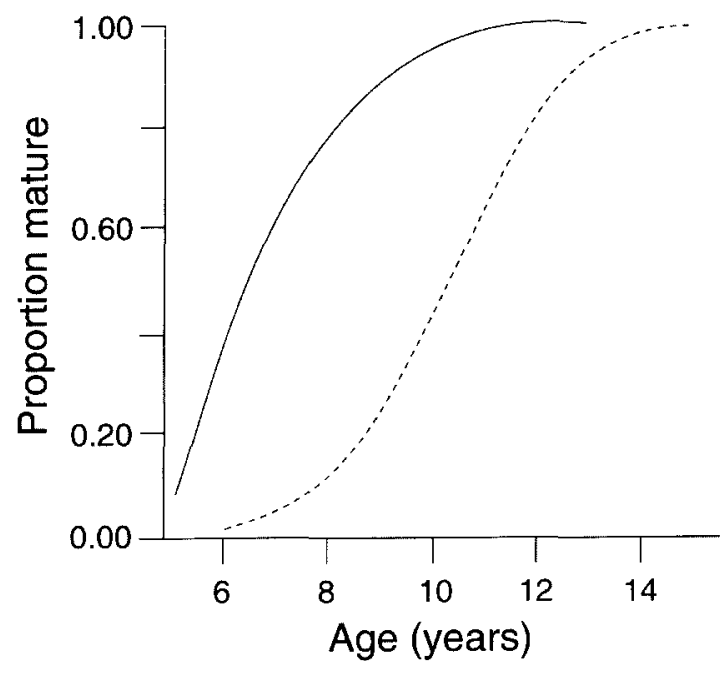

Fig. 2: Changes in maturity schedules (proportion of females mature as a function of age) for ArcticNorwegian cod. Gadus morhua morhua. Dashed line, 1930s-1940s. Solid line, 1960s-1970s. Replotted from Borisov' (1979).

bred fish compete with wild populations." These same cautions apply to marine fisheries, particularly given marine stock enhancement efforts and the expanding range of some species in ocean ranching (Ogura and Ito, 1994). Stock enhancement to augment wild populations, while increasing numbers. may reduce the genetically effective size of the total population (Ryman, 1991: Ryman et al., 1995). Unfortunately, these kinds of programs are highly attractive to and supported by the general public as a "technological fix" to a complex ecological problem (Hilborn, 1992; Smith, 1994). For further reading on this topic, sources of information are Lannan et al. (1989) and Beveridge et al. (1994).

Extinction of marine species, or at least genetically distinct substocks of a species, from overfishing may be a cause for concern. The dominant causes of extinction for freshwater fishes have been habitat destruction and introduced species, with overfishing a relatively minor component (Miller et al., 1989). The broader scale of the marine environment, however, may mean that most marine species exploited by fisheries have natural refuges where small populations prevent outright extinction (Jamieson. 1993; Huntsman. 1994). Only six of all threatened or endangered taxa on the federal list have marine or estuarine phases in their life history, and none are entirely oceanic; Huntsman (1994), however, noted 39 marine finfish species where population status should be examined for possible listing. A similar evaluation for marine invertebrates is probably warranted.

\section{Marine Fisheries and Species Diversity}

Fisheries have major impacts on the communities of marine animals and can have far-reaching effects on species-level diversity (defined here as syecies composition and relative dominance). Assemblages of fishes and other organisms are typically structured through a combination of morphoIngical specialization, predation, and some competition (Britz and Moyle, 1993). By changing the relative abundance of species, fisheries can disrupt these processes and thereby alter assemblage structure (Gulland. 1987).

Direct effects of fishing on species diversity are caused by removals of target species, bycatch of unwanted species, physical disturbance. and discards (Harris and Poiner, 1991). Because fisheries data programs record removals with varying degrees of accuracy but do not always consider discards, these effects have only been given scrutiny over the past 15 years (Alverson et al.. 1994). One of the best documented examples of by-catch is in the Gulf of Mexico, where shrimp fisheries cause mortality of the young stages of several commercially important marine fish species, affecting dynamics of those stocks. These same fisheries also directly impact other fishes and invertebrates. Mortality from capture and discard may also be species-specific (Fennessy, 1994; Kaiser and Spencer. 1995), potentially contributing to dominance of species that survive capture. Multiple stresses are involved in capture, however, so results of experimental work on survival after capture are often variable (Chopin and Arimoto, 1995). Estimates of discarded by-catch on a worldwide basis approach 27 million tons annually (Pauly and Christensen. 1995), demonstrating the magnitude of the bycatch problem.

By-catch of unintended species also occurs in pelagic fisheries. In the eastern tropical Pacific. for example, the ecological relationship between tuna and porpoise schools was used by tuna purse seine fishermen, who encircled dolphins to capture the yellowfin tuna schools typically found beneath them. In less than two decades, populations of two dolphin species were as low as $20-50 \%$ of the 1959 population estimates (Smith, 1983). Social pressure led to legal action, research programs, and ultimately "dolphin safe" tuna. Similar concerns about by-catch in large-scale drift-net fisheries in the North Pacific (Wetherall, 1991) led to international agreements to ban this type of fishing.

Indirect effects of fishing on species diversity have been observed in many cases, the most prominent being alteration of predator-prey interactions. Fisheries often develop on higher trophic level species (Deimling and Liss, 1994), thus reducing predation on, and possibly increasing production of, prey species (Marten. 1979). Gulland (1987) noted changes in the balance of small pelagic fish species due to changes in competition imposed by selective fishing. Similar fluctuations, however, also occur in the absence of fishing 
(Soutar and Isaacs, 1974); identifying the effects of fisheries on biodiversity is confounded by the unknown range of natural variation on medium to long time scales. That "regime shifts," or largescale decadal changes in the environment, affect many levels of marine ecosystems is becoming more evident (Polovina et al., 1994). Although these natural factors surely have implications for biodiversity at all levels, the superimposition of anthropogenic effects such as fishing doubtless exacerbates the resulting changes in the ecosystem (NRC, 1995). Moreover, potential genetic changes in stocks from fishing, as noted above. may alter the ability of stocks to respond to such changes.

Examples of fisheries effects on species assemblages abound. Hamre (1994) describes a "crisis" caused by fisheries in the Barents Sea. This relatively simple system was dominated by planktivorous herring and capelin and predatory cod. Overfishing of herring led to recruitment failure and a switch of the fishery to capelin. while cod stocks remained strong. Cod eventually failed because of lack of capelin and herring prey. Fish populations on Georges Bank changed from dominance by commercially important groundfish species to less desirable species such as dogfish and sandlance (Anthony, 1990). Concurrent with a decline in the desirable groundfish from overfishing were increases in pelagics (herring, mackerel) and elasmobranchs (spiny dogfish, skates; Fig. 3). Even seabird diversity may be affected by marine fisheries. In the North Sea, fisheries discards may represent $30 \%$ of the annual food consumption of seabirds; over time. this food source has led to population increases, particularly in scavenging seabird species (Gislason. 1994).

In many temperate and subarctic regions, sea urchins play important roles in structuring nearshore communities: fisheries may disturb that structure. Off eastern Canada, lobster is a key species controlling sea urchins, and when fisheries reduce lobster populations, urchin overgrazing may reduce kelp over large areas (Mann and Breen, 1972). Off the west coast of North America. human exploitation led to reduced numbers and range contraction of the sea otter, Enhydra lutris; reduced sea otter predation on large sea urchins in these systems also leads to significant reductions in kelp (Estes and Palmisano 1974). Off the northern California coast this situation had proceeded until the near-shore habitat had limited bull kelp, virtually no understory kelp, and high densities of large red urchins (Stronglyocentrotus franciscanus). In a $20-\mathrm{yr}$ time series of transect observations in this area, Hobson (personal communication) noted changes in the nearshore community after the development of a fishery for the red urchin in 1985. Removal of red urchins led to spatial expansion of bull kelp and, subsequently. development of lush understory kelp. A difference from the natural, sea otter-dominated community, however, is that the smaller, noncommercial purple sea urchin, $S$. purpuratus, moved into deeper water habitats formerly occupied by red urchins and grazed heavily on the understory kelp (E.H. Hobson, NMFS Tiburon Lab, personal communication).

Changes in species diversity under the artificial selection imposed by fisheries will typically favor species with certain life history characteristics. Adams (1980) reviewed the response of species with differing life-history traits to exploitation and concluded that $r$-selected species are favored over K-selected species. This has implications for the species mix likely to be dominant after continued exploitation. Those species will generally be early maturing, achieve a small maximum size rapidly, with high fecundity and a relatively short longevity; these characteristics describe small pelagic fishes, which often become major components of mature fisheries (Formacion and Saila, 1994) but unfortunately are subject to large natural fluctuations (Soutar and Isaacs, 1974). A notable exception is the increase of K-selected elasmobranchs on Georges Bank (Fig. 3). These were not subject to exploitation until recent years, so abundance increased. Fishes that are very long-lived, such as Sebastes (Fig. I) will be at a disadvantage when subjected to tisheries (Leaman, 1991). Orange roughy, another long-lived species, may not reach sexual maturity until $>30 \mathrm{yr}$ of age (Fenton et al., 1991), and fishing on such species may be more akin to mining than fishing.
Changes in species

diversity under the

artificial selection

imposed by fisheries

will typically favor

species with certain

life history character-

istics.

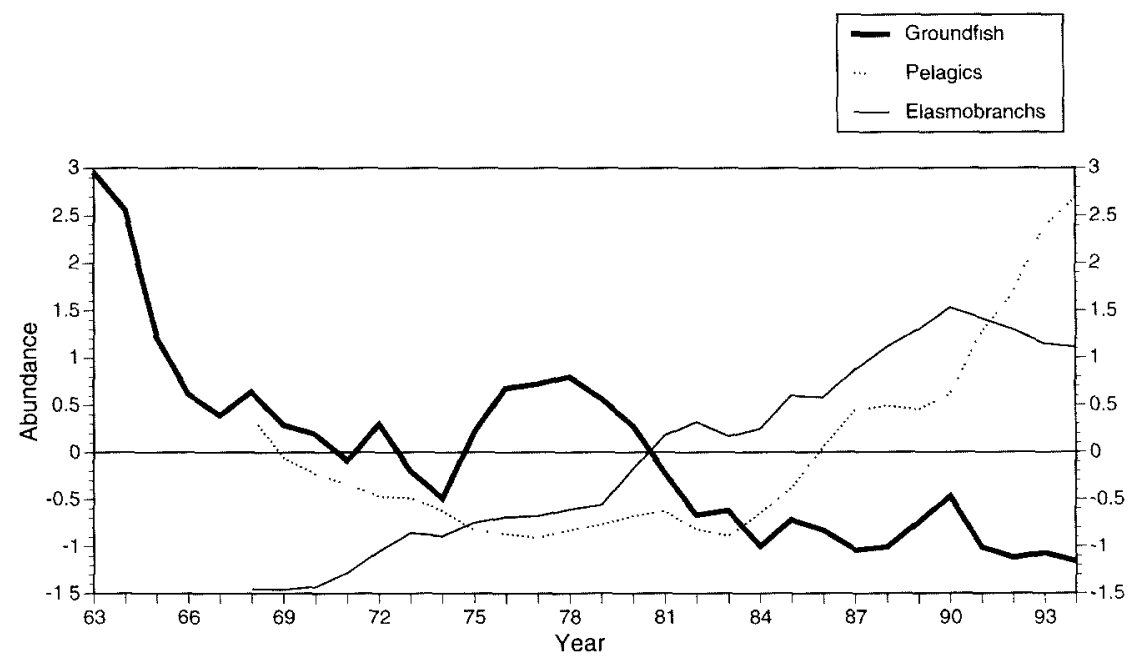

Fig. 3: Changes in the relative abundance (standardized index. based on survey data) of the principal species groups in the Georges Bank region. The "groundfish" group is comprised of 12 species including cod, haddock, and flounders; "pelagics" inclade herring and mackerel; and "elasmobranchs" include dogfish and skates. Data courtesy of S. Murawski, NMFS Northeast Fisheries Science Center (personal communication). 


\section{Marine Fisheries, Habitat Diversity, and Ecosystem Function}

Marine fisheries may alter and in some cases destroy habitats within the marine environment. Their effects on ecosystem function are complex and, in many cases, difficult to identify. Modification of habitats, changes in relative biomass of target and nontarget species, and the attendant alterations in the trophic web may lead to changes in energy flux. The broad scale of marine fisheries brings human impact to virtually all parts of the world's oceans.

Certain fishing gears may cause significant The changes in bio-

mass associated with

fisheries may alter

trophic or energy flow

pathways with conse-

quences for ecosys-

tem diversity and

productivity. change in habitat. An extensive literature exists, for example, on trawling impacts to benthic ecosystems (Jones, 1992). Short-term biological effects of trawls include direct mortality of more fragile fauna (e.g., urchins); 40-60\% reductions in density of such fragile benthos were recorded after three passes of a beam trawl (Gislason, 1994). Direct disturbance results in greater availability of prey for mobile predators (Kaiser and Spencer, 1994). Trawl marks in soft bottoms may remain for several years (Brylinski et al., 1994) and may be characterized by altered benthic communities dominated by species adept at colonizing disturbed habitats (Reise, 1982); the net effect is changed diversity. The scale of disturbance can be significant. Although trawling effort in the North Sea is patchy, the area swept annually by bottom trawls is equal to the total area of the North Sea (Gislason, 1994).

Physical damage to complex habitat by fishing can lead to long-term effects such as altered productivity. Sabellaria reefs damaged by trawling (Reise, 1982), coral reefs damaged by fish traps (Vanderknaap, 1993), and near-shore reefs destroyed by fisheries for date mussel in the

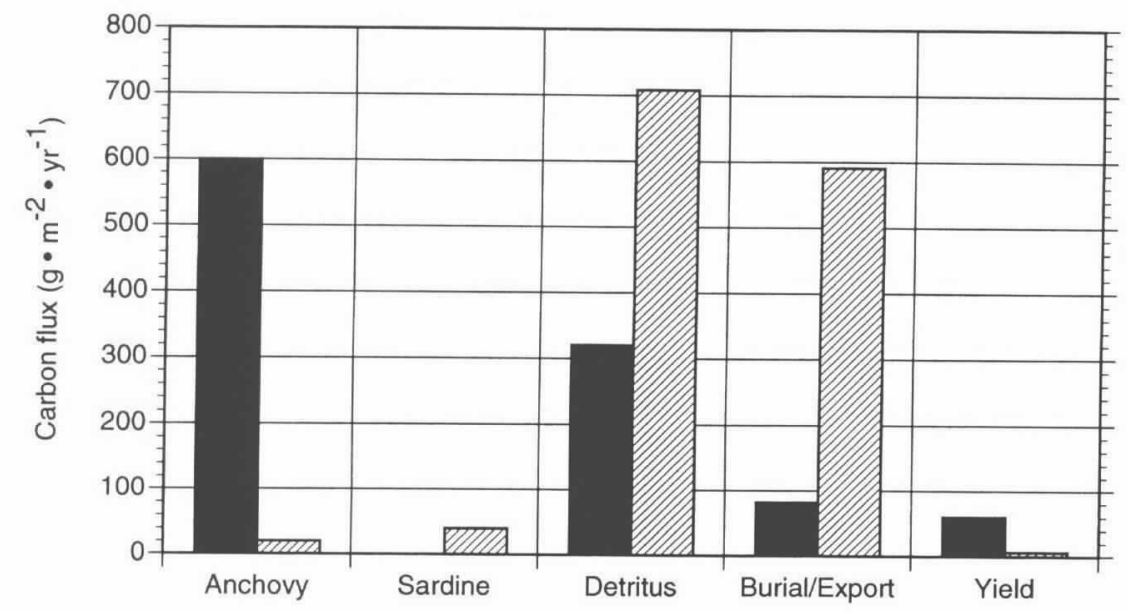

Fig. 4: Model-estimated changes in carbon flux for the Peruvian upwelling system during periods of high (1966-1969, solid bar) and low (1976-1979. crosshatched bar) anchoveta biomass. Values for anchovy, sardine, and detritus represent carbon inputs; burial/export is export from the detritus pool and yield represents the total fisheries yield. Data are from Walsh (1981).
Mediterranean (Fanelli et al., 1994) are examples. In the Chesapeake Bay, the drastic decline in oyster populations has variously been blamed on disease, water quality, or overfishing. Rothschild et al. (1994) analyzed the available data in detail and suggested that the major changes occurred long before water quality or disease were problems, thus directly implicating overfishing and habitat destruction. Fishing activities are but one cause of destruction of fisheries habitat; these concerns demand immediate attention (NOAA, 1995a).

The changes in biomass associated with fisheries may alter trophic or energy flow pathways with consequences for ecosystem diversity and productivity. Under the agency of fisheries in the southern ocean, the decline of the great whales may have resulted in dramatically increased availability of krill in the Antarctic (Laws, 1977), which in turn may have caused changes in the growth rates and ages at sexual maturity in other marine mammals (Bengston and Laws, 1985). Some of this production is also taken in krill fisheries (FAO, 1993). Another indirect impact of historical whale fisheries has been a reduction of whale-falls to the deep sea, leading to reduced recruitment sites for deep-sea benthic fauna (Butman et al., 1995). Where lower trophic levels are changed through fishing, the effects may be even more dramatic. Walsh (1981) described striking changes in the carbon budget of the Peruvian upwelling ecosystem before and after decreases in the anchoveta population (caused by a combination of overfishing and environmental change). Anchovy consumption of primary and secondary productivity decreased 300 times, and the anchovy yield to fisheries decreased 30-fold. Estimates of carbon going to the detrital pool more than doubled, and detrital carbon exported or buried increased sevenfold. At the same time, the total fisheries yield declined to $11 \%$ of its former value (Walsh, 1981) (Fig. 4). Although more recent data and simulation models have suggested the changes to be less drastic because of uncertainties about zooplankton grazing and the level of primary production (Jarre-Teichmann, 1992), the potential impact to patterns of energy flow within an ecosystem can be immense.

\section{Fishery Management, Sustainability, and} Biodiversity

An oft-cited but anthropocentric view of the benefits of biodiversity is maintenance of ecosystem resiliency to continue to provide humans with "valued ecological services" (Hammer et al., 1993). Unfortunately, the potential for further growth of marine fisheries is limited (Pauly and Christensen, 1995). Maintaining production of the current protein needs for humans from the sea requires improved management of existing stocks or aquaculture and ocean ranching. Aquaculture can have major impacts on biodiversity including in- 
troduction of exotic species and genetic introgression with wild stocks (Lannan et al.. 1989) and the impacts "are rarely positive, occasionally neutral, but usually negative to some extent" (Beveridge et al., 1994). In Japan, coastal fisheries have been maintained at a near constant level by increasing mariculture production while natural tish production has declined (Morikawa, 1994). The best example of "successful" ocean ranching is chum salmon. Young are released into the North Pacific Ocean in immense numbers, leading to high production but concerns for the carrying capacity of the ecosystem as the open-ocean range of this species increases (Ogura and Ito, 1994). Such technological approaches to enhance or augment natural stocks should be approached with caution because the genetic and ecosystem implications to biodiversity are complex (Ryman. 1991; Hilborn. 1992). Unfortunately, these programs have developed on large scales with insufficient attention paid to the range of potential impacts.

An international perspective on the recent history of tisheries suggests four epochs (Garcia and Newton, 1994). A period of post-war reconstruction (1945-1958) was followed by geographical expansion (1959-1972). With declaration of 200mile exclusive economic zones (EEZ), the period from 1973 to 1982 involved establishment of a new economic order of the oceans. The final epoch, after 1983, was a transitional period toward global concerns for fisheries. Fisheries research and management must become attuned to sustainable management of stocks, minimizing undesirable side effects of fishing on habitats and ecosystems. and conserving marine environmental quality (FAO, 1993; Gislason, 1994). Although a variety of international resolutions exist, they have not always been implemented at the national policy level; a current example of international efforts is the FAO International Code of Conduct for Responsible Fisheries (Garcia and Newton. 1994).

Conservation of aquatic biodiversity is not an organized venture in the United States. Many laws address biodiversity concerns. but the effort has been characterized as "piecemeal" (Winter and Hughes, 1995). Marine fisheries in the United States are managed by a mixture of state agencies for near-shore fisheries and the National Marine Fisheries Service, part of the National Oceanic and Atmospheric Administration (NOAA), for largerscale fisheries in the U.S. EEZ. The current NOAA Strategic Plan (NOAA, 1995b) emphasizes building sustainable fisheries and conserving resources and the habitats on which they depend. The vision statement in the "Environmental Stewardship Portfolio" promises that NOAA will lead in preservation of marine biodiversity by balancing exploitation of natural resources with the management of protected species and ensure that coastal ecosystems are managed to maintain biodiversity and long-term productivity for sustained use. Most biodiversity concerns are expressed in the chapters "Recover Protected Species" and "Sustain Healthy Coasts" but are not always carried through to the chapter "Build Sustainable Fisheries" (see NOAA, 1995a). The latter chapter does not explicitly define the importance of biodiversity to fisheries or recognize the potential impacts of tisheries to biodiversity; it also encourages marine aquaculture to enhance or accelerate the recovery of depleted stocks without fully considering negative effects.

Legal authority for management under the Magnuson Fishery Conservation and Management Act (under which fishery management plans are developed) gives no consideration to genetic, species, or ecosystem biodiversity except as it affects protected species or critical habitats. Given that marine fisheries is one of the key "critical environmental issues" confronting maintenance of biodiversity (NRC, 1995), such policies should be reevaluated in light of the potential impacts of marine fisheries on biodiversity. A variety of management approaches exists that can take these concerns into account. Research on multispecies or ecosystem management has come a long way (Shelton, 1992; Sherman, 1994), but the approach is not at a stage for implementation. Harvest refugia represent an important opportunity to manage biodiversity while managing fisheries (Roberts and Polunin, 1993: Bohnsack and Ault, 1996, this issue): more research on the functions and limitations of harvest refugia at varied spatial and temporal scales is sorely needed. Finally, because marine tisheries represent one of the greatest manipulations of marine ecosystems by humans. the opportunity exists to learn a great deal about perturbations, ecological processes, and ecosystem response. Adaptive fisheries management (Walters and Hilborn, 1978) uses management regimes in an experimental manner to learn about the processes regulating fish population size as well as interactions among species. Fishery management regimes can thus provide the opportunity to carefully examine ecosystem response and to monitor. understand, and hopefully predict the consequences in terms of likely changes in biodiversity at all levels of complexity.

\section{Conclusions}

Fisheries science has a rich history of research contributions to population dynamics and evaluation of marine ecosystems, and a great deal of the long-term data used to evaluate natural variation is based on fisheries. Recently, the ability of fisheries to be managed in a sustainable manner has been questioned (Ludwig et al., 1993), due in large part to the complexity of the ecological and social/cultural systems involved. Others have argued that positive examples from the past, learning from past errors, and new understanding of resource fluctuations make sustainable use an attainable ob- 
jective (Rosenberg et al., 1993). Biodiversity is a critical element in ecosystem function, and thus in maintaining sustainable populations.

In conclusion, biodiversity is an important issue to fisheries and should be of concern to fishery managers. Many of the effects of marine fisheries on biodiversity are distinct and obvious. but evidence is circumstantial or lacking for some of the potentially most devastating effects. On the time scale of decades, however, fisheries can change genetic, species, and ecosystem diversity from levels that have been achieved over millions of years through natural selection. There is little doubt that such changes in biodiversity will decrease the resiliency of species, communities, and ecosystems to respond to natural perturbations that occur on longer time scales. It is thus critical to understand the alterations that fisheries and other anthropogenic changes have wrought on marine biodiversity and to develop strategies that will ameliorate future ecological changes. The requisite research will go beyond simple inventories (Renner and Ricklefs, 1994) and will require process-oriented studies at the regional level (NRC, 1995). Fisheries have major impacts on marine biodiversity; long-term sustainability of these fisheries may be dependent on the very diversity that they are changing.

\section{Acknowledgements}

I thank Bruce Leaman for data on the age composition of Sebastes alutus and Steve Murawski for information on the abundance of Georges Bank fish assemblages. John Graves. Mary Yoklavich, and Mike Vecchione made valuable comments on an earlier version of the manuscript.

\section{References}

Adams, P.B., 1980: Life history patterns in marine fishes and their consequences for fisheries management. Fish. Bull., U.S., 78, 1-12.

Alverson. D.L.. M.H. Freeburg. S.A. Murawski and J.G. Pope. 1994: A global assessment of tisheries bycatch and discards. FAO Fisheries Tectinical Paper, 339, 233 p.

Anthony, V.. 1990: The New England groundfish fishery after 10 years under the Magnuson Fishery Conservation and Management Act. North Am. J. Fish. Manage.. 10. $175-184$.

Bengston, J.L. and R.M. Laws, 1985: Trends in crabeater seal age at maturity: an insight into Antarctic marine interactions. In: Antarctic Nutrient Cycles and Food Webs. W.R. Siegfried, P.R. Condy and R.M. Laws, eds. Springer-Verlag, Berlin, 670-675.

Beveridge, M.C.M., L.G. Ross and L.A. Kelly, 1994: Aquaculture and biodiversity. Ambio, 23, 497-502.

Bohnsack, J.A. and J.S. Ault, 1996: Management strategies to conserve marine biodiversity. Oceanography 9, 73-82.

Borisov, V.M., 1979: The selective effect of fishing on the population structure of species with a long life cycle. $J$. Ichthyol., 18, 896-904.

Britz, D.M. and P.B. Moyle, 1993: Invasion resistance to introduced species by a native assemblage of Californian stream fishes. Ecol. Applications. 3, 246-255.

Brylinsky, M.. J. Gibson and D.C. Gordon, 1994: Impacts of flounder trawls on the intertidal habitat and community of the Minas Basin, Bay of Fundy. Can. J. Fish. Aquat. Sci., $51,650-661$
Butman. C.A., J.T. Carlton and S.R. Palumbi, 1995: Whaling effects on deep-sea biodiversity. Conserv. Biol., 9. $462-464$.

Carvalho, G.R., 1993: Evolutionary aspects of fish distribution-genetic variability and adaptation. $J$. Fish Biol., 43. 53-73.

Chopin, F.S. and T. Arimoto, 1995: The condition of fish escaping from fishing gears-A review. Fish. Res., 2l, $315-327$.

Deimling. E.A. and W.J. Liss. 1994: Fishery development in the eastern North Pacific: a natural-cultural system perspective, 1888-1976. Fish. Oceanogr., 3, 60-77.

DeMartini. E.E.. D.M. Ellis and V.A. Honda. 1993: Comparisons of spiny lobster. Panulirus marginatus fecundity, egg size, and spawning frequency before and after exploitation. Fish. Bull., U.S., 91, 1-7.

Estes, J.A. and J.F. Palmisano, 1974: Sea otters: their role in structuring nearshore communities. Science, 185. $1058-1060$

Fanelli, G., S. Piraino, G. Belmonte, S. Geraci and F. Boero, 1994: Human predation along apulian rocky coasts iSE Italy)-Desertification caused by Lithophaga lithophaga (Mollusca) fisheries. Mar. Ecol. Prog. Ser., 110, $1-8$.

FAO Marine Resource Service. 1993: Review of the state of world marine fishery resources. FAO Fisheries Tech. Pap., $335,136 \mathrm{p}$.

Fennessy, S.T.. 1994: Incidental capture of elasmobranchs by commercial prawn trawlers on the Tugela Bank, Natal, South Africa. S. Afr. J. Mar. Sci., 14, 287-296.

Fenton, G.E. S.A. Short and D.A. Ritz, 1991: Age determination of orange roughy, Hoplostethus atlanticus (Pisces. Trachichthyidae) using Pb-210:Ra-226 disequilibria. Mar. Biol., 109, 197-202.

Formacion, S.P. and S.B. Saila, 1994: Markov chain properties related to temporal dominance changes in a Philippine pelagic fishery. Fish. Res., 19, 241-256.

Garcia, S.M. and C.H. Newton, 1994: Responsible fisheries: an overview of FAO policy developments (1945-1994). Mar. Pollut. Bull., 29, 528-536.

Garrod. D.J. and J.W. Horwood. 1984: Reproductive strategies and the response to exploitation. In: Fish Reproduction: Strategies and Tactics. G.W. Potts and R.J. Wootton. eds. Academic Press, New York. 367-384.

Gislason. H., 1994: Ecosystem effects of fishing activities in the North Sea. Mar. Pollut. Bull., 29. 520-527.

Gobert, B.. 1992: Impact of the use of trammel nets on a tropical reef resource. Fish. Res., 13, 353-367.

Gulland, J.A., 1987: The effect of fishing on community structure. S. Afr. J. Mar. Sci., 5, 839-849.

Hammer, M., A. Jansson and B.O. Jansson. 1993: Diversity change and sustainability-implications for fisheries. Ambio, 22, 97-105.

Hamre, J., 1994: Biodiversity and exploitation of the main fish stocks in the Norwegian-Barents Sea ecosystem. Biodiversity Conservation, 3, 473-492.

Harris, A.N. and I.R. Poiner, 1991: Changes in species composition of demersal fish fauna of Southeast Gulf of Carpentaria, Australia, after 20 years of fishing. Mar. Biol., III, 503-519.

Hilborn. R., 1992: Hatcheries and the future of salmon in the Northwest. Fisheries, 17, 5-8.

Huntsman, G.R.. 1994: Endangered marine finfish: neglected resources or beasts of fiction? Fisheries, 19, 8-15.

Jamieson, G.S., 1993: Marine invertebrate conservation: evaluation of fisheries over-exploitation concerns. Amer. Zool., 33, 551-567.

Jarre-Teichmann, A., 1992: Steady-state modelling of the Peruvian upwelling ecosystem. Ph.D. Thesis, University of Bremen, Germany, $153 \mathrm{pp}$.

Jones, J.B., 1992: Environmental impact of trawling on the seabed: a review. N. Z. J. Mar. Fresh. Res., 26, 59-67.

Kaiser, M.J. and B.E. Spencer, 1994: Fish scavenging behav- 
iour in recently trawled areas. Mar. Ecol. Prog. Ser., $1 / 2,41-49$.

and B.E. Spencer. 1995: Survival of by-catch from a beam trawl. Mar. Ecol. Prog. Ser. 126. 31-38.

Lannan. J.E., G.A.E. Gall, J.E. Thorpe. C.E. Nash and B.E. Ballachey, 1989: Genetic resource management of fish. Genome, 31, 798-804.

Larsen. P.L.. P.S. Albert and D.L. Riddle, 1995: Genes that regulate both development and longevity in Caenorhab ditis elegans. Genetics, 139, 1567-1583.

Laws, R.M.. 1977: Seals and whales of the Southern Ocean. Phil. Trans. R. Soc. Lond. B. Biol. Sci., 279, 81-96.

Leaman. B.M., 1991: Reproductive styles and life history variables relative to exploitation and management of Sehastes stocks. Env. Biol. Fish. 30, 253-271.

Ludwig. D., R. Hilborn and C. Walters, 1993: Uncertainty. resource exploitation, and conservation: lessons from history. Science, $260.17,36$.

Mann, K.H. and P.A. Breen, 1972: The relation between lobster abundance. sea urchins, and kelp beds. J. Fish. Res. Bd. Cancda. 29. 603-609.

Marten, G.G.. 1979: Predator removal: effect on fisheries yields in Lake Victoria (East Africa). Science, 203, 646-648.

McAllister, M.K.. R.M. Peterman and D.M. Gillis. 1992: Statistical evaluation of a large-scale fishing experiment designed to test for a genetic effect of size-selective fishing on British Columbia pink salmon $\left(\mathrm{On}^{-}\right.$ corhynchus gorbuscha). Can. J. Fish. Aquat. Sci.. 49. 1294-1304.

M.Fadden, J.T., 1977: An argument supporting the reality of compensation in fish populations and a plea to let them exercise it. In: Assessing the Effects of Power-Plant $\mathrm{m}$ duced Mortality on Fish Populations. W. Van Winkle. ed. Pergamon Press. New York, 153-183.

Miller, R.R., J.D. Williams and J.E. Williams, 1989: Extinctions of North American fishes during the past century. Fisheries, 14, 22-38.

Moav, R., T. Brody and G. Hulata, 1978: Genetic improvement of wild fish populations. Science, 201, 1090-1094.

Morikawa, T., 1994: Maintenance of the fisheries environment and efforts to increase the resources in the coastal waters of Japan. Mar. Pollut. Bull., 29, 537-549.

National Occanic and Atmospheric Administration. 1993: Our Living Oceans: Report on the Status of U.S. Living Marine Resources, 1993. NOAA Tech. Memo, NMFSF/SPO- 15 , Washington, DC. $156 \mathrm{pp}$.

1995a: NOAA Strategic Plan: A Vision for 2005. U.S Department of Commerce, Washington. DC.

1995b: NOAA Strategic Plan: A Vision for 2005. Executive Summary. NOAA. U.S. Department of Commerce. Washington. DC, $21 \mathrm{pp}$.

National Research Council, 1995: Understanding Marine Biodiversity: a Research Agenda for the Nation. Committee on Biological Diversity in Marine Systems. National Academy Press, Washington, DC, $114 \mathrm{pp}$.

Ogura. M. and S.O. Ito, 1994: Change in the known ocean distribution of Japanese chum salmon, Oncorhynchus keta, in relation to the progress of stock enhancement. Can. J. Fish. Aquat. Sci., 51. 501-505.

Parma, A.M. and R.B. Deriso, 1990: Dynamics of age and size composition in a population subject to size-selective mortality - effects of phenotypic variability in growth. Can. J. Fish. Aquat. Sci., 47. 274-289.

Parrish. R.H., C.S. Nelson and A. Bakun. 1981: Transport mechanisms and reproductive success of fishes in the California current. Biol. Oceanogr., 1. 175-203.

Pauly, D. and V. Christensen, 1995: Primary production required to sustain global fisheries. Nature. 374. 255-257.

Polovina, J.J., G.T. Mitchum. N.E. Graham, M.P. Craig. E.E.
DeMartini and E.N. Flint, 1994: Physical and biological consequences of a climate event in the central North Pacific. Fish. Oceanogr., 3, 15-21.

Regier. H.A. and K.H. Loftus, 1972: Effects of tisheries exploitation on salmonid communities in oligotrophic lakes. J. Fish. Res. Bd. Can., 29, 959-968.

Reise, K.. 1982: Long-term changes in the macrobenthic invertebrate fauna of the Wadden Sea: are polychaetes about to take over? Neth. J. Sea Res., 16, 29-36.

Renner. S. and R.E. Ricklefs, 1994: Systematics and biodiversity. Trends Ecol. Evol., 9. 78.

Rijnsdorp. A.D.. 1993: Fisheries as a large-scale experiment on life-history evolution-disentangling phenotypic and genetic effects in changes in maturation and reproduction of North Sea plaice. Pleuronectes platessa L. Oecologia, 96, 391-401.

Roberts. C.M. and N.V.C. Polunin, 1993: Marine reservessimple solutions to managing complex fisheries. Ambio, 22, 363-368.

Rosenberg. A.A.. M.J. Fogarty, M.P. Sissenwine, J.R. Beddington and J.G. Shepard, 1993: Achieving sustainable use of renewable resources. Science, 262, 828-829.

Rothschild. B.J., J.S. Ault, P. Goulletquer and M. Heral. 1994: Decline of the Chesapeake Bay oyster population: a century of habitat destruction and overfishing. Mar. Ecol. Prog. Ser., 111, 29-39.

Ryman, N.. 1991: Conservation genetics considerations in fishery management. J. Fish Biol., 39(Suppl. A), 211-224. F. Utter and L. Laikre. 1995: Protection of intraspecific biodiversity of exploited fishes. Rev. Fish Biol. Fish., 5, 417-446.

Shelton, P.A., 1992: Detecting and incorporating multispecies effects into fisheries management in the North-West and South-East Atlantic. S. Afr. J. Mar. Sci., 12, 723-737.

Sherman, K., 1994: Sustainability. biomass yields, and health of coastal ecosystems-an ecological perspective. Mar. Ecol. Prog. Ser., 112, 277-301.

Smith, P.J., R.I.C.C. Francis and M. McVeagh, 1991: Loss of genetic diversity due to fishing pressure. Fish. Res., 10, 309-316.

Smith. T.D., 1983: Changes in size of three dolphin (Stenella spp.) populations in the eastern tropical Pacific. Fish. Bull. U.S., 81, 1-13.

1994: Scaling Fisheries: the Science of Measuring the Effects of Fishing, 1855-1955. Cambridge University Press, Cambridge. $392 \mathrm{pp}$.

Soutar, A. and J.D. Isaacs, 1974: Abundance of pelagic fish during the 19th and 20th centuries as recorded in anaerobic sediment off the Californias. Fish. Bull., U.S., 72. 257-273.

Vanderknaap. M.. 1993: Physical damage to corals caused by trap-fishing on reefs of Bonaire, Netherlands Antilles. Env. Conserv., 20, 265-267.

Walsh, J.J., 1981: A carbon budget for overfishing off Peru. Nature, 293, 300-304.

Walters. C.J. and R. Hilborn. 1978: Ecological optimization and adaptive management. Annu. Rev. Ecol. Syst., 9, $157-188$.

Wetherall, J.A., ed., 1991: Biology, Oceanography and Fisheries of the North Pacific Transition Zone and Subarctic Frontal Zone. NOAA Tech. Rept. NMFS, 105, $111 \mathrm{pp}$.

Wilcove. D., M. Bean and P.C. Lee, 1992: Fisheries management and biological diversity: problems and opportunities. Trans. N. Am. Wildl. Nat. Res. Conf., 57, 373-383.

Winter, B.D. and R.M. Hughes. 1995: AFS Draft position statement on biodiversity. Fisheries, 20, 20-26.

Wohlfarth, G.W.. 1986: Decline in natural fisheries-a genetic analysis and suggestion for recovery. Can. J. Fish. Aquat. Sci., 43, 1298-1306. 